\title{
Use of Steel Fiber Reinforced Concrete for the Protection of Buildings Against High Dynamic Actions
}

\author{
Vahan Zohrabyan, Thomas Braml, Tobias Zircher and Manfred Keuser \\ University of German Armed Forces, Chair for Concrete Construction, \\ Werner-Heisenberg-Weg 39, 85577 Neubiberg, Germany, vahan.zohrabyan@unibw.de
}

\begin{abstract}
Nowadays ensuring the safety of people and the protection of infrastructure is a socially relevant topic, which requires a thorough investigation.

The Institute of concrete construction at the University of the German Armed Forces in Munich is investigating the possibilities of using steel fiber concrete for the protection of military facilities and state-owned special buildings in Germany. In this research project steel fiber reinforced concrete is investigated under high dynamic loads specifically under contact detonation loading. Plates with varying reinforcement systems, different thicknesses, different fiber geometries, fiber contents and fiber types were produced.The following concrete compressive strengths C20/25, C40/50, C80/95 were used in this research project.The plates were loaded with $500 \mathrm{~g}, 750 \mathrm{~g}, 1000 \mathrm{~g}, 1500 \mathrm{~g}$ and $2000 \mathrm{~g}$ PETN explosive at the test facility of the German Armed Forces Technical centre for Protective and Special Technologies. An important property of construction material during ballistic threats and contact detonation is the concrete tensile strength. Through the addition of fibers, the post cracking behavior and the ductility of concrete components can be improved. All fiber-reinforced specimens showed less damage than the non-fiber reinforced elements. The aim of the study is to optimize the concrete mixture for the fiber concrete protection components considering the following factors: concrete quality, fiber content, fiber geometry, as well as aggregate size of the concrete. Another aim is to record and evaluate the damage parameters of the steel fiber reinforced concrete slabs after the highly dynamic load, and to investigate to offer suggestion for retrofitting. In this article, the test results of different steel framed concretes under highly dynamic conditions are presented.
\end{abstract}

Keywords: High Dynamic Load, Protective Components, Contact Detonation, Steel Fiber Reinforced Concrete, Damage Crater.

\section{Introduction}

As the number of people increases, the demand for both residential and public and stateowned buildings and infrastructures is increasing.

Taking into account the fact that mass influx of people to major cities is taking place lately, the demand for these buildings is increasing, resulting in higher prices for their construction, rent and service.

As the problem grows more serious and attracts a lot of construction space, it should be resolved as soon as possible by offering clear solutions. A solution to the problem for example can be the use of construction materials, structures and construction technologies that will make the structure more robust and durable (suitable for long-term use).

The resistance, security and durability of buildings for state and military facilities are set in completely different criteria such as embassies, military bases, nuclear power plants, chemical factories, government buildings, and so on. 
Reconstruction or retrofitting work in these structures is always associated with high costs and high risks e.g.:

- the control should be increased during the construction works

- depending on the technological process, the production lines are partially or completely shifted which are associated with additional costs and effort

- auxiliary things, ammunition and workers should also be resettled

as a result, these buildings become more vulnerable and their normal operation is disrupted (one should not forget the fact that these facilities are the target of recent terrorist attacks).

In general, the protection of state-owned special buildings from possible terrorist attacks can be done in the following ways:

1. newly constructed buildings: depending on the significance of the building and the risks of the attack, the material must be defined and selected so that during the possible attack it ensures the safety of the objects and people (excluding of injuries and hazards in the shelter).

2. allready constructed buildings: Depending on the significance of the building, the risks involved in the attack and the design, the protection can be implemented in the following ways:
a) by reinforcing work
b) by using an additional facade protection panel

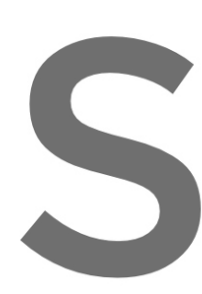

\section{Material and $\mathrm{C}$}

The Institute of Concrete Construction at the
the possibilities of using steel fibre reinforced
and state-owned federal buildings in Germany.
In this research project, reinforced concrete
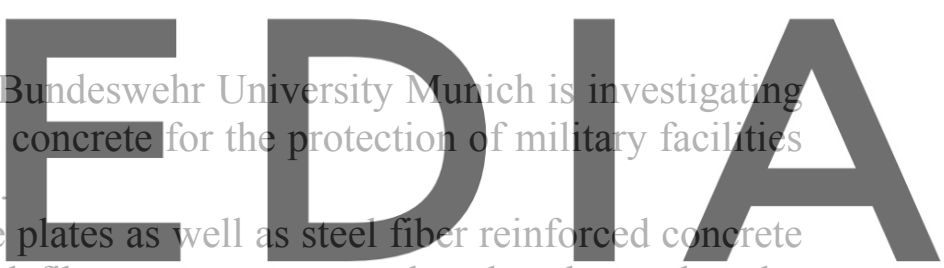

plates made of different geometries and steel fiber content are produced and tested under

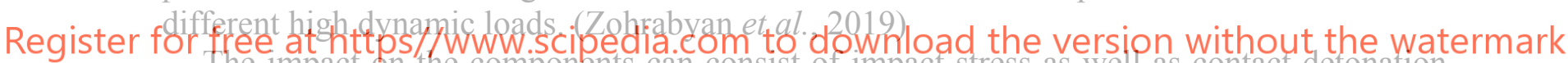
the impact on the components can consist of impact stress as well as contact detonation,

near or far, from e.g. suicide bombers, vehicles loaded with explosives, etc.

For the construction of sensitive German Armed Forces infrastructure buildings and for buildings in out-of-area-operations, it is therefore necessary to consider these scenarios in design and service and to show to which extent the use of fiber reinforced concrete can lead to an improvement of the protective effect.

Within the framework of this research project, the protective wall and facing structures made of steel fiber reinforced concrete are investigated. Numerous experimental investigations are carried out.

The aim of the study is to make the panels as thin and light as possible in order to allow them to be attached to existing facades as a protective element. (Zircher et al., 2019)

Since in many buildings the panels cannot be fixed to the front of the building depending on the architectural solution, the protective wall would be used as a second alternative. The crash barrier panels should also be as light and thin as possible and must withstand both shock waves and impact loads. Here it is important that the panels can be produced in an economically favourable way and installed easily. 


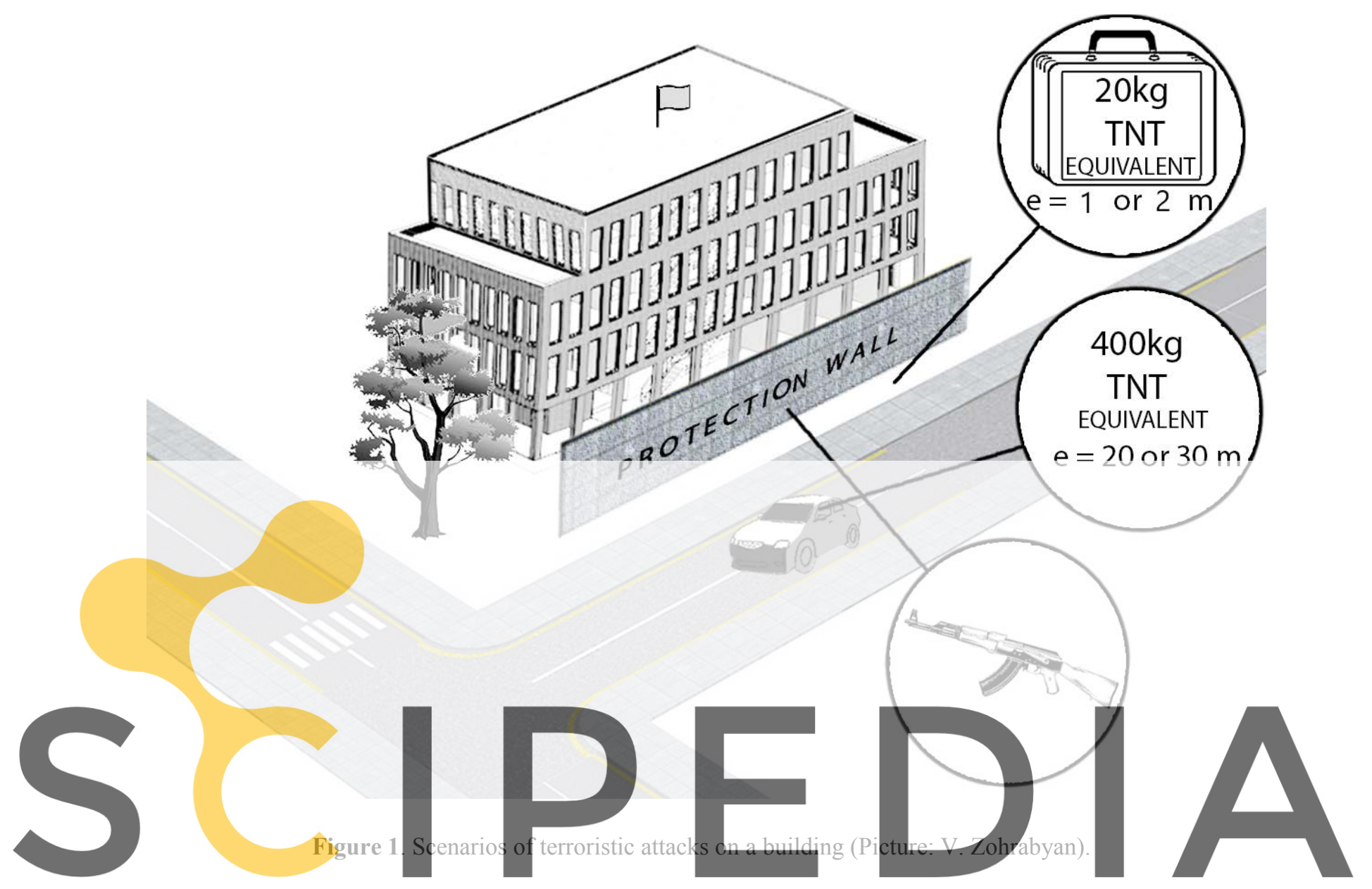

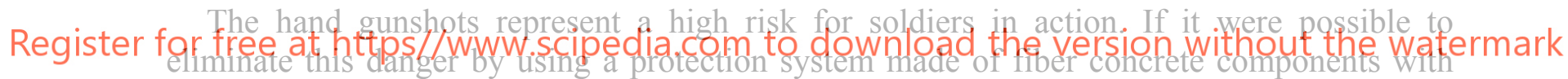

exclusion of secondary debris, part of the task would be solved. In order to slow down or

completely intercept the secondary debris that flakes off as a result of the bombardment, the fiber reinforced concrete slabs will in future be equipped with a kind of steel grid curtain. In the following, the first test results of the fiber reinforced concrete slabs with high compressive strength concrete C80/95 under hand gunshot are presented. 

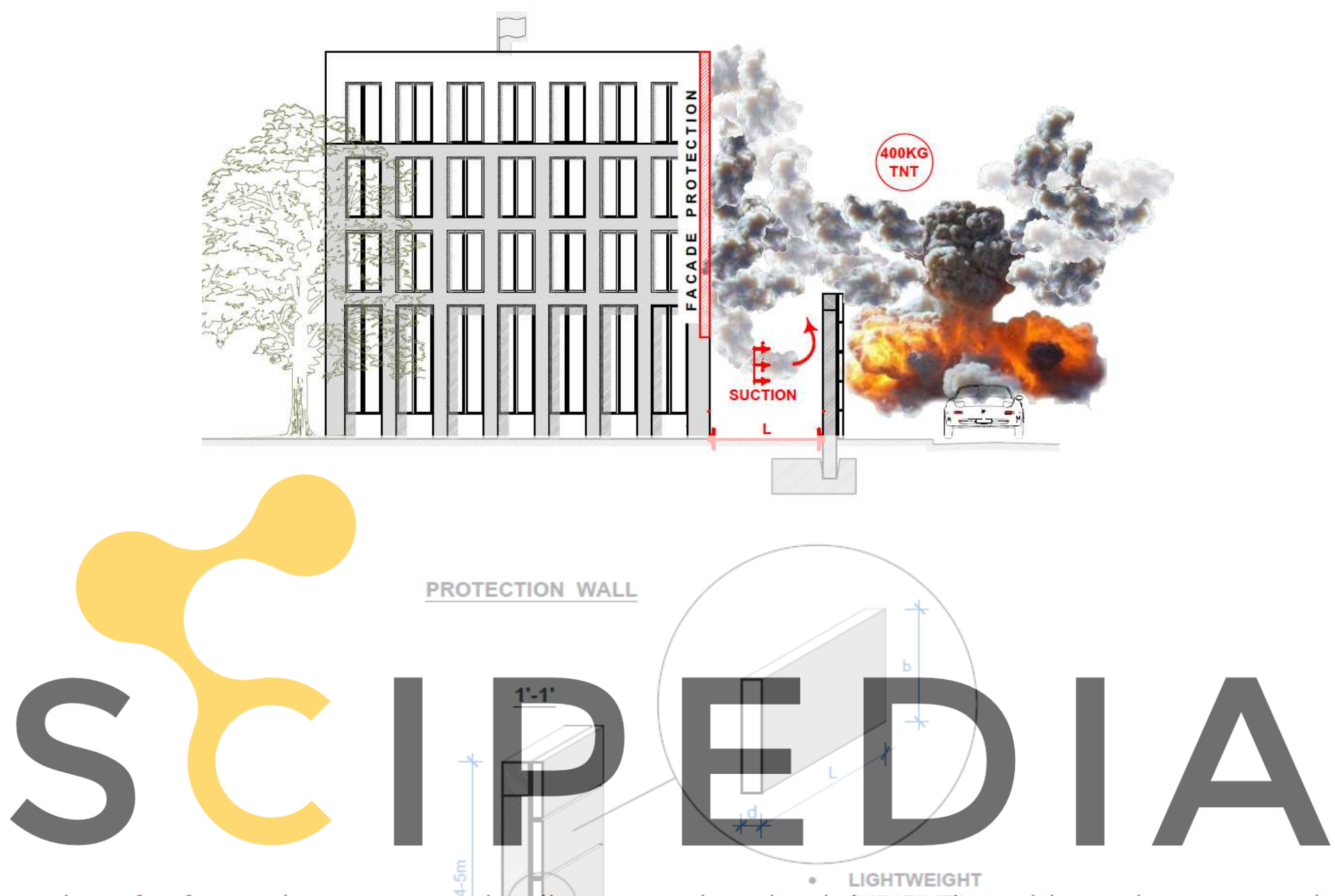

Register for free at https//www.scipedia.com to download the the

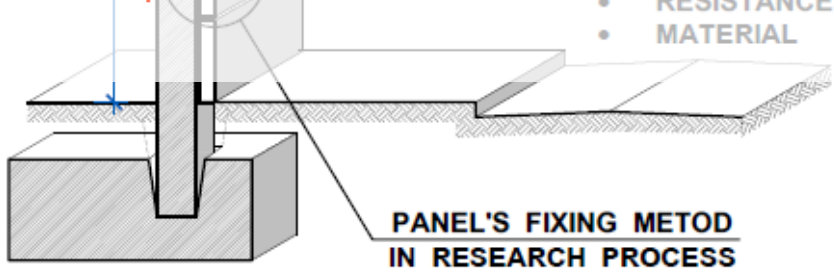

Figure 2. Attack with a car bomb with $400 \mathrm{~kg}$ TNT equivalent according to STANAG 2280 (Picture: V. Zohrabyan).

\section{Concrete Mixtures and Plate Production for Hand Gunshot Tests}

In this project there were produced four concrete mixtures, each consisting of 3 test specimens with different fiber types (polypropylene fibers and steel fibers). As steel fiber types, here it is used: Krampeharex KH DE35/0,55 N (length: $35 \mathrm{~mm}$, diameter:0,50 mm, tensile strength: $1350 \mathrm{~N} / \mathrm{mm}^{2}$ ), (KRAMPEHAREX GmbH and Co. KG, 2017) BASFMF 254 (length: $54 \mathrm{~mm}$, diameter: 0,81 mm, tensile strength: $552 \mathrm{~N} / \mathrm{mm}^{2}$ ), BASFMF 249 (length: $48 \mathrm{~mm}$, diameter: 
0,85 mm, tensile strength: $400 \mathrm{~N} / \mathrm{mm}^{2}$ ) and BASF MF 244 (length: $40 \mathrm{~mm}$, diameter: $0,81 \mathrm{~mm}$, tensile strength: $\left.552 \mathrm{~N} / \mathrm{mm}^{2}\right)$.(BASF, 2017) The composition of the fiber concrete C80/95 is shown in Table 1.

Table 1.Concrete Composition Mix 1-4. (Kustermann et al., 2005) (Günter and Vollenschaar, 2011) (Richter, 2002) (Thienel and Kustermann, 2017)
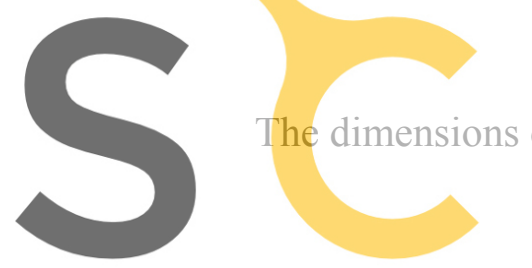

\begin{tabular}{|l|l|}
\hline Ingredients concrete mixture & Mix 1-4 \\
\hline Cement II/BM(S-D)52,5N & $459 \mathrm{~kg} / \mathrm{m}^{3}$ \\
\hline Stoneash & --- \\
\hline Aggregate 0/4 NfGK & $784,9 \mathrm{~kg} / \mathrm{m}^{3}$ \\
\hline Aggregate 4/8 NgGK & $419,8 \mathrm{~kg} / \mathrm{m}^{3}$ \\
\hline Aggregate 8/16 NgGK & $620,6 \mathrm{~kg} / \mathrm{m}^{3}$ \\
\hline Water & $145 \mathrm{~kg} / \mathrm{m}^{3}$ \\
\hline (W/C-ratio) & 0,316 \\
\hline Superplasticizer & $2,55 \%$ \\
\hline Fiber content & $1 \mathrm{Vol} \% \mathrm{for}$ Mix 1 to 4 \\
\hline Steel fiber KH DE35/0,55 N & $78,5 \mathrm{~kg} / \mathrm{m}^{3}$ (Mix 1) \\
\hline Polypropylene fiber MF 244 & $9,1 \mathrm{~kg} / \mathrm{m}^{3}($ Mix 2) \\
\hline Polypropylene fiber MF 254 & $9,1 \mathrm{~kg} / \mathrm{m}^{3}($ Mix 3) \\
\hline Polypropylene fiber MF 254 & $9,1 \mathrm{~kg} / \mathrm{m}^{3}$ (Mix 4) \\
\hline Plate thickness & $6 \mathrm{~cm}$ \\
\hline Consistency & $\mathrm{F} 4$ \\
\hline \\
of the fiber reinforded plates are 300 \\
\hline
\end{tabular}

Register for free at https//www.scipedia.com to download the version without the watermark

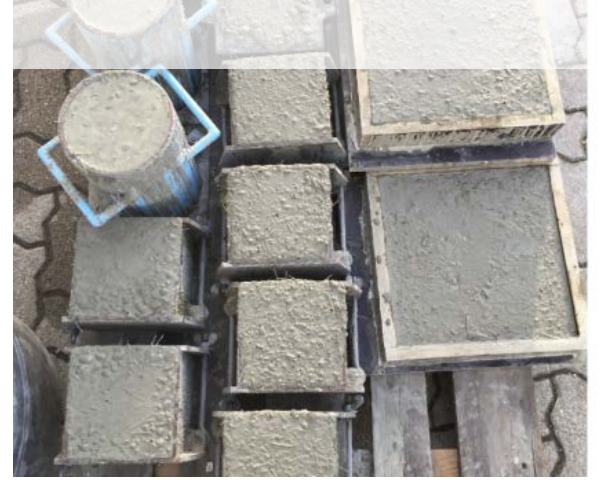

Figure 3. Production of test specimens.

\section{Hand Gunshot Test}

The hand gunshot tests were carried out in the laboratory of the Institute of Ballistics Weapons and Munition at the Bundeswehr University Munich. 


\subsection{Test Setup and Execution}

The $300 \times 300 \times 60 \mathrm{~mm}$ thick fiber concrete plates were shot with both soft- and hard-core shot caliber $7.62 \mathrm{~mm}$ x 51308 Winchester. The projectiles have a weight of $9.5 \mathrm{~g}$ for soft core and $9.8 \mathrm{~g}$ for hard core. These were fired by the ammunition tester series 1055 , which can be seen in the foreground in Figure 4.

The velocities of the projectiles were determined by measurement of two light barriers LS $23 \mathrm{~F} 3 / \mathrm{K} 2$. These measure the speed with an accuracy of $\pm 0,1 \%$. An average bullet speed velocity is $842.75 \mathrm{~m} / \mathrm{s}$ and an average projectile energy computed 3373.03 Joule. The camera was used in the bullet trap (Figure 4) which was triggered as soon as the projectile hit the plate.

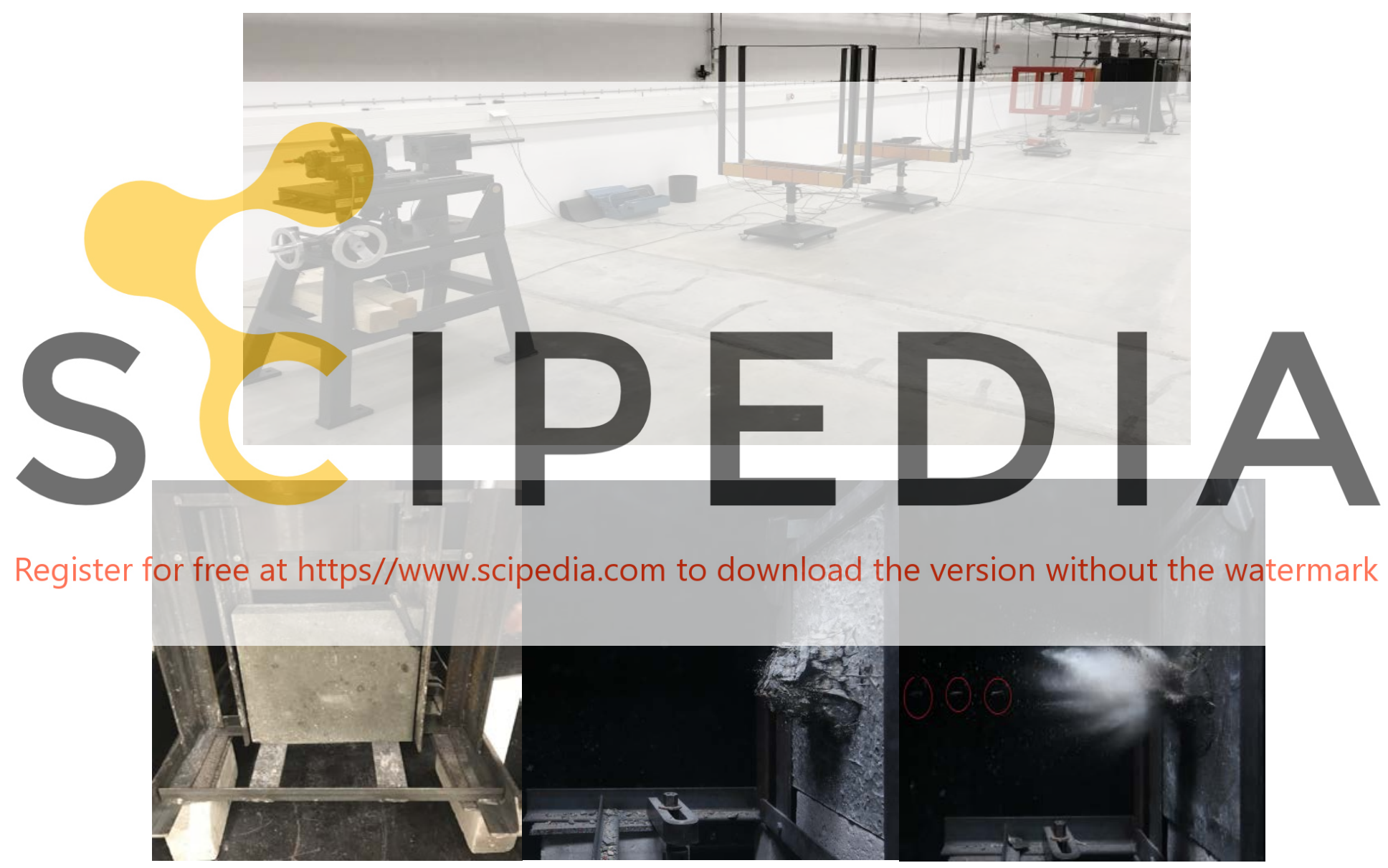

Figure 4. Setup and execution of hand gunshot test.

\subsection{Results}

In order to measure the damage caused by the projectile, the $6 \mathrm{~cm}$ thick plates fired on were analyzed with regard to the crater volume (Figure 5).

The crater volume on the firing frontside and the opposite side as well as their mean values are given in Table 2 and compared Figure 6. 

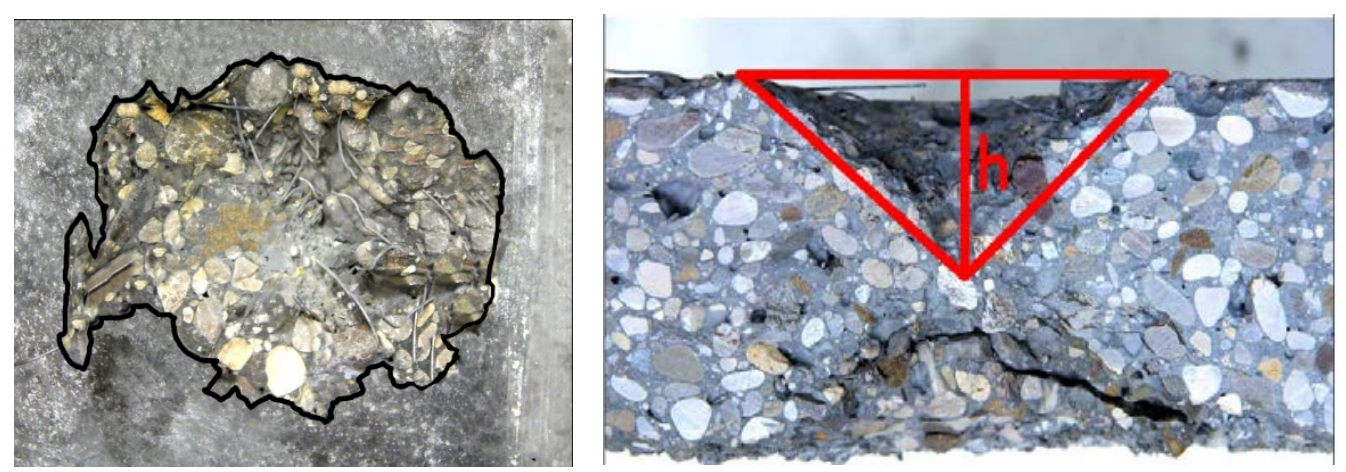

Figure 5. Crater volumes.

Table 2. Mean crater volume front and backside.

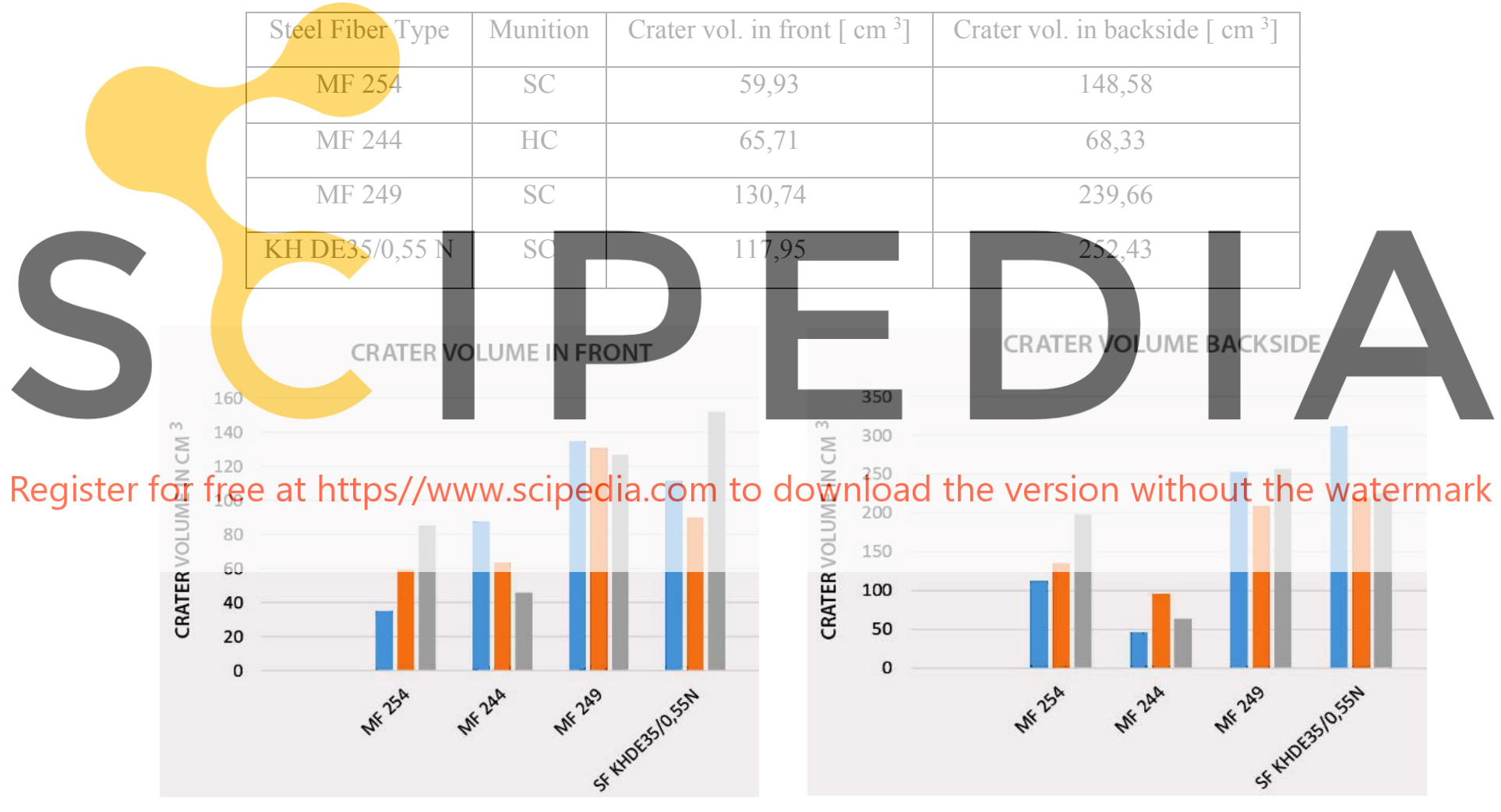

Figure 6. Evaluation of crater volumes.

\section{Conclusions}

The aim of the presented study was to develop a high-performance concrete mix of high strength fiber concrete for the production of protective components, which was achieved.

- During the processing of the high-strength standard and fiber concrete, it turned out that a very high use of personnel compaction energy is required to ensure target- 
oriented processing.

- The steel fibers KH DE35/0.55 $\mathrm{N}$ have the best effect in concrete in terms of increasing compressive strength and improving energy absorption when shot at with soft-core ammunition. The plates of this mixture showed a good protective capacity and withstood the shots well. (Michal et al., 2014)

- It can be said that the specimens produced with fiber Masterfiber 249 also showed good results. It has to be said, however, that the fiber MF 249 only slowed down the projectile and did not stop it.

In conclusion, it can be said that it is possible to manufacture protective components from fiber reinforced, high-strength concrete.

Depending on the dimension and depth of damage after dynamic loading, the created cracks and voids in concrete components can be repaired and strengthened by impregnation and injection. The following variants are possible:
1) Closing the damage area: The aim is corrosion protection. It prevents the chloride entering the component.
2) Sealing the damaged area: The aim is to eliminate water-bearing cracks.
3) Frictional connection: The aim is to create a frictional connection between the two sides of the crack.

\section{Acknowledgements}

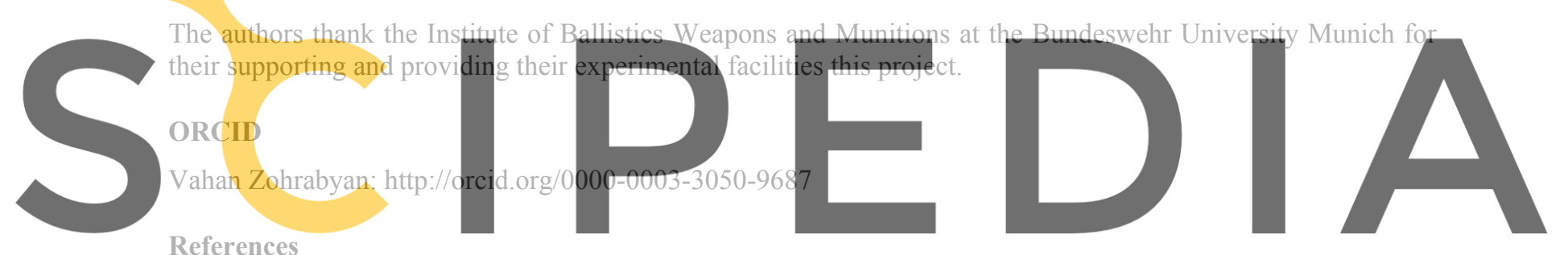

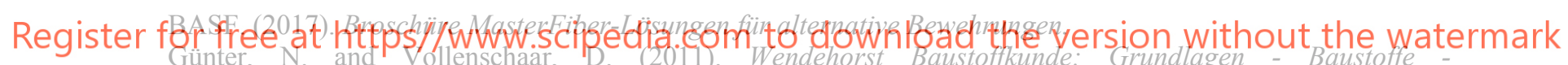
Oberflächenschutz; mit 363 Tabellen. Vieweg+Teubner Verlag / Springer Fachmedien Wiesbaden GmbH Wiesbaden, Wiesbaden, 27., voliständig überarbeitete Auflage Auflage.

KRAMPEHAREX GmbH and Co. KG. (2017). Datenblatt Produkt Drahtfaser DE 35/0,55N.

Kustermann, A., Keuser, M. and Grimm R. (2005). Hochfeste Bindemittel und Zuschlagstoffe für hochfeste Betone unterschiedlicher Güte für Schutzanlagen der militärischenSonderinfrastruktur. Universität der Bundeswehr München, Neubiberg: Doctorarbeit.

Michal, M., Keuser, M. and Frey, M. (2014). Effects of a new Steel Fiber in Concrete under Small-Caliber Impact. Universität der Bundeswehr München, Neubiberg: Doktorarbeit.

Richter, Th. (10.2002). Zement Merkblatt Betontechnik Hochfester Beton / Hochleistungsbeton B16,.

Thienel, K.-Ch. and Kustermann A. (2017). Sonderbetone: Normalbeton, Hochfester Beton, Hochleistungsbeton, Ultrahochfester Beton. Neubiberg.

Zircher, T., Keuser, M., Braml, Th., Berg, A. and Burbach, A. (Oct. 21-25, 2019). 18th International Symposium for the Interaction of Munitions with Structures. Investigations on the use of fiber concrete for infrastructure prptection. in Panama City Beach, FL, USA.

Zohrabyan, V., Braml, Th., Zircher, T. and Keuser, M. (Oct. 21-25, 2019). 18th International Symposium for the Interaction of Munitions with Structures. The residual load bearing capacity of reinforced concrete as well as steel fiber reinforced concrete components after contact detonation. in Panama City Beach, FL, USA. 